\title{
Avifaunal Diversity of Barandabhar Corridor Forest, Chitwan, Nepal
}

\section{Praveen Kumar Jha}

Department of Zoology, Tri-Chandra Multiple Campus, Tribhuvan University, Kathmandu, Nepal

Email: jhapraveenkumar8@gmail.com

\section{Debendra Prasad Dhakal}

Department of Zoology, Makawanpur Multiple Campus, Hetauda

Email: debdhakal@gmail.com

\section{Corresponding Author}

\section{Praveen Kumar Jha}

DOI: https://doi.org/ 10.3126/irjmmc.v2i4.41555

Received: December 12, 2021; Revised \& Accepted: December 21, 2021; Published: December 22, 2021

(C) Copyright: Jha (2021).

\section{ABSTRACT}

The main aim of the study was to analyze the avifaunal diversity of Chitwan, Nepal. The avifaunal diversity at six transects of Barandabhar Corridor Forest in Chitwan district was carried out during two visits (autumn and spring) in 2020-2021. The line transect method was used to cover most of the study area. In total, 125 species of birds representing 18 orders and 59 families were recorded. The highest number of bird species i.e. (56) 44.8\% were represented by order Passeriformes along with 34 families. The highest number of species was found in family Picidae (9) 7.2\% followed by Cuculidae (8) $6.4 \%$ and least number (1) $0.8 \%$ in other 31 families. The seasonal status of species was Autumn (84) and Spring (116). The relative abundance of species was Very Common (60), Common (40), Uncommon (16), and Rare (9). According to the National Red List of Nepal's Birds, 110 species were in the Least Concern category, eight species were in the Near Threatened category, six species were in the Vulnerable category and one species was in the Critically Endangered category. It was noted that major threats to the birds were illegal fishing, noise pollution, firewood collection, illegal cattle grazing, and invasive alien plant species. One Globally Threatened Bird Lesser Adjutant Leptoptilos javanicus was also noted.

Keywords: Birds, Corridor Forest, Diversity, Family, Season

\section{INTRODUCTION}

There are around 10,000 live bird species on the planet (Mensing, 2011). Birds vary in their habitats, diversity, abundance, and distribution throughout the world (Singh, 2015). One of the most important ecological indicators for evaluating the quality of habitats is avifaunal diversity. Nowadays, avifaunal diversity has decreased due to the destruction of natural habitats and human disturbances (Sarkar et al., 2009). Forests attract a large number of avifauna because they provide suitable habitats for most birds, especially those birds that are associated with vegetation, and for most, the existing trees are a vital component of their life 
cycle (Koli, 2014). Birds are extremely important ecologically because of their important roles as pollinators and seed dispersers (Bibi \& Ali, 2013). Nepal's birdlife is one of the richest one in the world considering the country's small size; its biodiversity strength is well reflected with a high number of bird species. So far, 886 species have been recorded in Nepal (BCN \& DNPWC, 2018) which are about 9\% of the total bird species found worldwide. However, according to Bird Life International (2020), 43 species recorded in Nepal are listed in the IUCN Red List of globally threatened birds. Among these, nine (20.9\%) species are Critically Endangered, eight (18.6\%) Endangered, and 26 (60.4\%) are listed as Vulnerable. A total of 168 species of birds of Nepal has been identified as Nationally Threatened that included 68 (40\%) Critically Endangered species, 38 (23\%) Endangered species, and 62 (37\%) Vulnerable species (Inskipp et al., 2017)). Forests and scrubland hold the highest proportion of $77 \%$ of the country's breeding birds (Baral \& Inskipp, 2004). These habitats are especially important for Nepal's restricted-range species.

Nepal's only endemic bird is the Acanthoptila nipalensisis (Spiny Babbler) (Inskipp et al., 2016). As per the National Parks and Wildlife Conservation (NPWC) Act 1973; nine species of birds; Himalayan Lophophorus impejanus (Monal), Catreuswallichii (Cheer Pheasant), Tragopan satyra (Satyr Tragopan), Houbaropsis bengalensis (Bengal Florican), Sypheotidesindicus (Lesser Florican), Buceros bicornis(Great Hornbill), Grus Antigone (Sarus Crane), Ciconia nigra (Black Stork) and Ciconia ciconia (White Stork) are protected birds of Nepal (DNPWC 1973). The avifauna of Barandabhar forest has been studied in past by few workers (Dahal, 2002; Baral \& Inskipp, 2005) and Barandabhar Corridor Forest (Adhikari et al., 2018). Sharma (2004) studied the diversity of threatened birds and recorded 12 nationally threatened species of birds including two critically endangered birds in Barandabhar Corridor Forest. Ghimire (2009) studied the birds of the Barandabhar forest and recorded 123 species from the Barandabhar forest and wetlands.

\subsection{RESEARCH GAP}

The avifauna of Barandabhar forest has been studied in past by few workers (Dahal 2002; Baral \& Inskipp, 2005) and Barandabhar Corridor Forest (Adhikari et al., 2018). Sharma (2004) found the diversity of threatened birds and recorded 12 nationally threatened species of birds including two critically endangered birds in Barandabhar Corridor Forest. Ghimire (2009) studied the birds of the Barandabhar forest and recorded 123 species from the Barandabhar forest and wetlands. Despite these works, some areas of the Barandabhar forest were unattended; therefore, the present study was undertaken and it aims to give further information about diversity, relative abundance, habitat, and seasonal status of birds.

\section{MATERIALS AND METHODS}

\subsection{Study Area}

The Barandabhar forest is located between $84^{\circ} 22^{\prime} 30^{\prime \prime} \mathrm{E}$ and $84^{\circ} 33^{\prime} 0^{\prime \prime}$ E longitude, and $27^{\circ} 34^{\prime} 7^{\prime \prime} \mathrm{N}$ and $27^{\circ} 43^{\prime} 30^{\prime \prime} \mathrm{N}$ latitude in the Terai region in Chitwan district of Narayani zone. It covers an area of 12300 hector with an altitude range of 150-400m (Ghimire, 2009). It ranges from 1.8-7 Km in width and stretches from Chitwan National Park in the south to the Mahabharat range in the north. The forest south of the Mahendra Highway lies in the park's buffer zone. This is an extremely important forest corridor, providing a migratory passage 
route for birds and other wildlife (Dahal, 2002). The forest area includes Shorea robusta forest, riverine forest (Trewia nudiflora,Bombax ceiba, Mallotus philippensis, Dalbergia sissoo, Acacia catechu), mixed forest, shrubs, and wetlands (streams, lakes, canals and water holes) (Adhikari et al., 2000; Dahal., 2003). Beeshazari Lake; a Ramsar site that lies within the forest corridor is an important wetland for birds and other wildlife (Adhikari et al., 2019). The Barandabhar forest Important Bird Area (IBA) is important for the globally threatened species like Leptoptilos javanicus (Lesser Adjutant), Haliaeetus leucoryphus(Pallas's Fish Eagle), Aquila hastate (Indian Spotted Eagle), Aquila clanga(Greater Spotted Eagle), Buceros bicornis(Great Hornbill), and near-threatened Aythya nyroca (Ferruginous Pochard), Ichthyophaga ichthyaetus (Grey-headed Fish Eagle), Ichthyophaga humilis (Lesser Fish Eagle), Mycteria leucocephala (Painted Stork), Ephippiorhynchus asiaticus (Black-necked Stork) and Anhinga melanogaster (Darter) (Baral \& Inskipp, 2005 ). The major mammals found in the Barandabhar forest are Rhinoceros unicornis (Indian Rhinoceros), Elephas maximus(Asian Elephant), Axisaxis (Chital), Pantheratigris (Tiger), etc. The forest area suffers from encroachment for collection of firewood, fodder, and other forest products, livestock grazing, tree felling by local people, illegal timber removal on a larger scale, and forest clearance near villages (Adhikari et al., 2000). The Barandabhar forest has a range of climate season's winter, spring, and monsoon with a subtropical climate. The monsoon begins at the end of May and continues until September and the mean annual rainfall was $192 \mathrm{~mm}$ and highest in July $(604.8 \mathrm{~mm})$, lowest in January $(0.9 \mathrm{~mm})$, and no rainfall in December (Department of Hydrology \&Meteorology, overnment of Nepal, 2020).

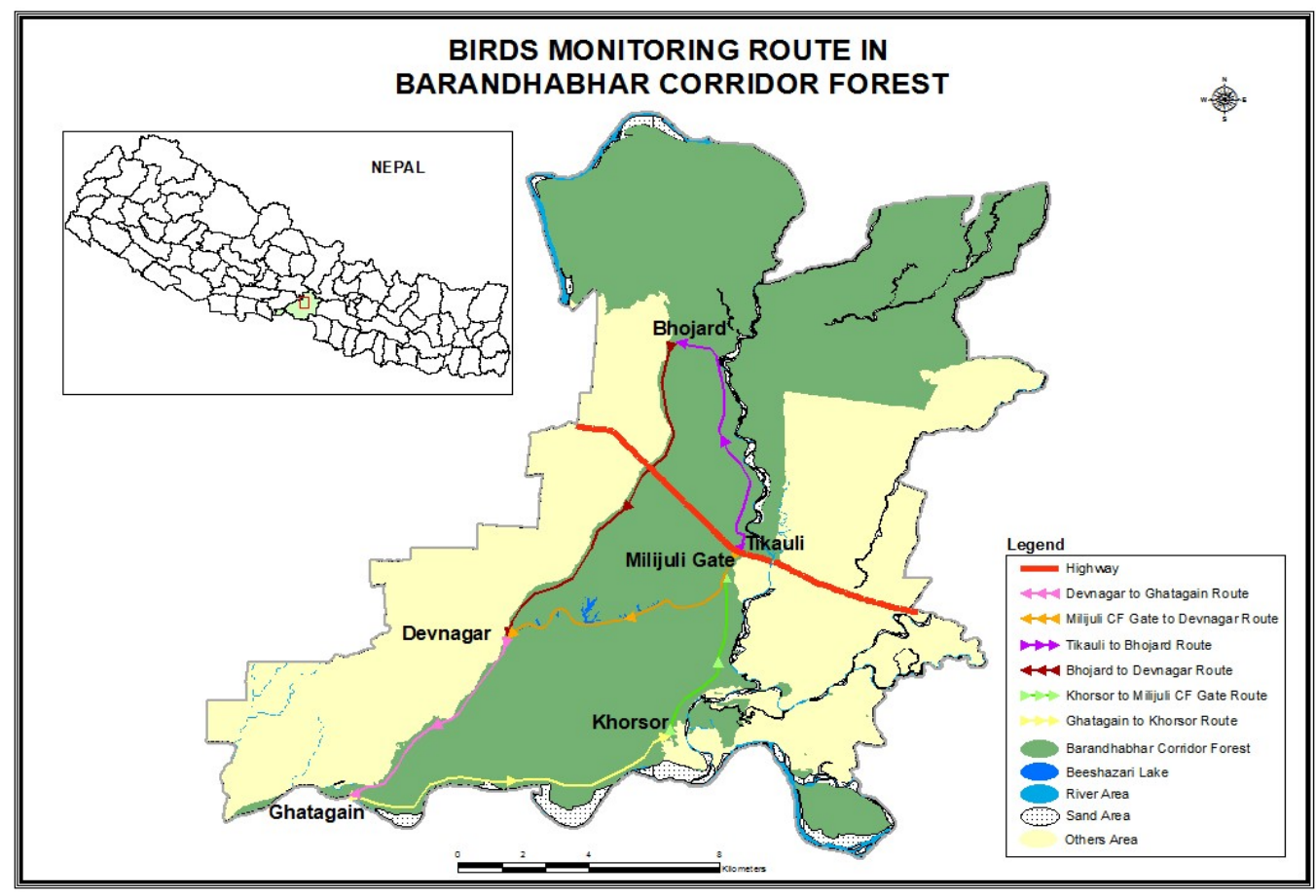

Fig. 1. Location Map of Study Area 


\subsection{METHODOLOGY}

Bird survey was carried out at Barandabhar Corridor Forest in October 2020 and May 2021 covering two different seasons (autumn and spring). The line transect sampling method was used to evaluate the bird diversity and their habitat association. Line transects methods with an ingrained tendency to have lower bias and higher precision are useful for the detection of birds that occur at low densities (Buckland 2006; Gale et al., 2009). A total of six-line transects (Fig. 1) were laid down to cover major habitat types and bird hot spot areas of the study area as well. The birding routes cover different habitats i.e. wetland, Sal- forest, riverine forest, grassland, forest edge, and residential area. Six transects were divided according to the permanent transect made by the Government of Nepal which included: (1) Tikauli gate to Bhozad along the Khageri river (2) Bhozad to Devnagar Range post (3) Devnagar Range Post to Ghatghain (4) Ghatghain to Khorsor (Elephant center) (5) Khorsor to Tikauli (Millijuli CF gate) (6) Tikauli Gate to Devnagar range post along with Beeshazari Lake. The survey was conducted on the designated birding route on foot to record the birds on the left (approximately 20-30 m) or right side (approximately 20-30 m) of the transect line. Minimum 2-3 days were given to each transect during each visit. The observations were made in the morning (7:00-10:00 AM) and evening (15:00-18:00 PM) at the local time under sufficient sunlight, since the peak activity of most birds lasts for one or two hours after sunrise and before the sunset. Once a survey was commenced, not recorded birds were left behind or beyond the transect line. As bright colors easily scare birds, such dresses were not worn. In addition, mist net was avoided during the survey. The relative abundance of bird species was estimated based on the frequency of sightings and the number of birds seen. The seasonal status of bird species was evaluated based on the presence or absence of birds during two different seasons. The IUCN Red List of Threatened Species and the National Red List of Nepal's Birds were also used to compare the national status with the global status. The birds were observed visually by Opticron Verano $8 \times 42$, RSPB $8 \times 42$ waterproof binoculars, and photographs were taken with a Canon Power Shot $5 \times 40$ HS. In addition, field guides Birds of the Indian Subcontinent 2011 by Grimmett, Inskipp and Inskipp, and Birds of Nepal (Grimmett et al. 2016) were used as field guides to identify the birds in field. Finally, a bird list was compiled by a careful recording of all birds observed.

\section{RESULTS AND DISCUSSION}

\subsection{Status of bird species}

A total of 125 species of birds belonging to 18 orders and 59 families were recorded from two different seasons (Table 1). The total number of species found in 18 orders were (Table 1; Fig.2): Galliformes (2) 1.6\%, Anseriformes (1) $0.8 \%$, Piciformes (10) $8 \%$, Bucerotiformes (2) 1.6\%, Coraciiformes (8) 6.4\%, Cuculiformes (8) 6.4\%, Psittaciformes (4) $3.2 \%$, Caprimulgiformes (1) $0.8 \%$, Strigiformes (2) $1.6 \%$, Columbiformes (5) 4\%, Gruiformes (1) $0.8 \%$, Charadriiformes (7) 5.6\%, Accipitriformes (6) 4.8\%, Falconiformes (1) $0.8 \%$, Suliformes (1) $0.8 \%$, Pelecaniformes (6) $4.8 \%$, Ciconiiformes (4) $3.2 \%$, and Passeriformes (56) 44.8\%. 


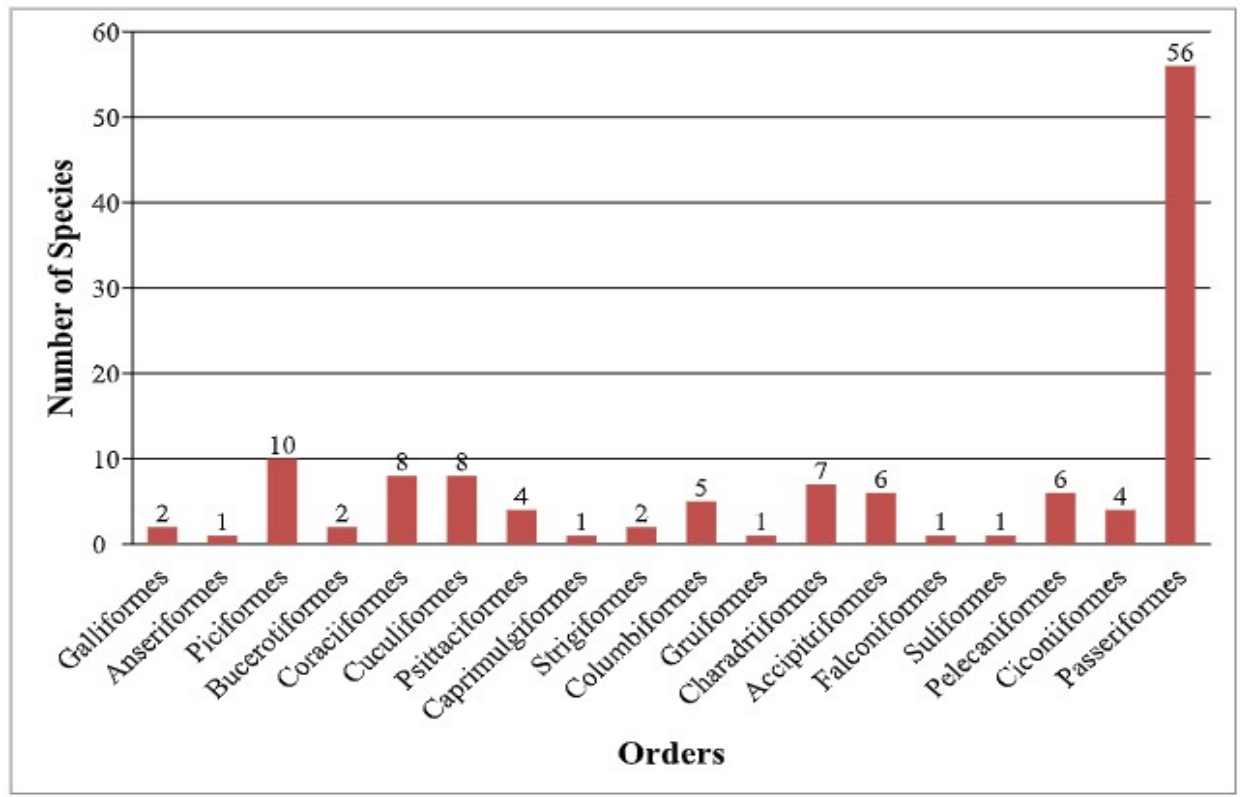

Fig. 2. Order-wise distribution of bird species in Barandabhar forest

The highest number of species was found in family Picidae (9) $7.2 \%$ followed by Cuculidae (8) $6.4 \%$ and least number (1) $0.8 \%$ in other 31 families (Table 1). The highest number of species was found in order Passeriformes (56) 44.8\% followed by order Piciformes (10) $8 \%$ and least number (1) in other 5 orders. 84 species of birds were recorded in autumn and 116 in the spring season.

\section{Seasonal fluctuation of the species}

The seasonal status of species was Autumn (84) and Spring (116)(Table 1; Fig.3). The spring season was found more favourable for bird diversity than autumn.

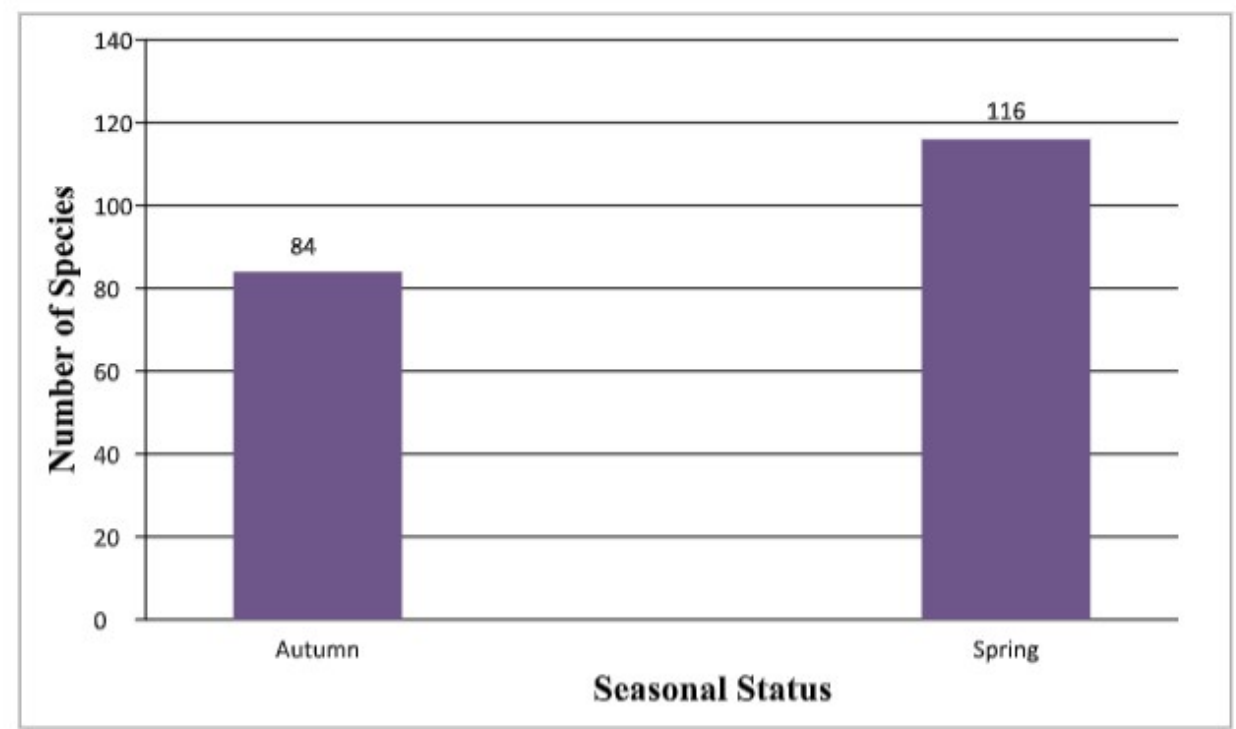

Fig. 3. Seasonal Status of bird species in Barandabhar forest 


\section{Relative abundance of the bird species}

The relative abundance of species (Fig. 4) was Very Common (60), Common (40), Uncommon (16), and Rare (9). Thus, the highest number of species was found in very common followed by common, uncommon, and

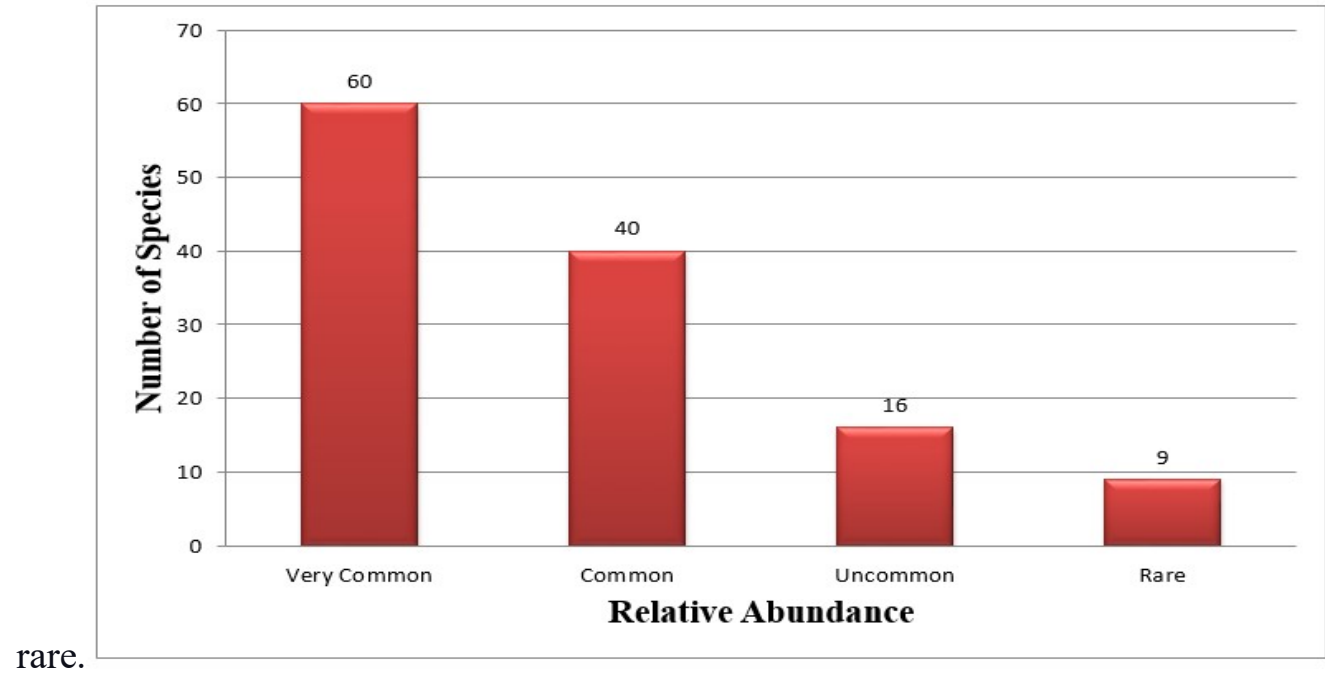

Fig. 4. Relative abundance of bird species in Barandabhar forest

National Trust for Nature Conservation (NTNC) formerly known as KMTNC (2005) recorded 303 bird species in the Barandabhar forest, which belonged to 15 orders and 54 families. Bird Education Society (1999) recorded 269 bird species in the Barandabhar forest. Similarly, Dahal (2002) has recorded 228 bird species from the same area. Likewise, Baral and Inskipp (2005) reported 282 species of birds from the Barandabhar forest and Beeshazari Lake. The number of bird species in my study seems low when compared to the data recorded by earlier authors. This could be a limitation of this study covering only two seasons (autumn and spring) where birds not to be recorded are left behind or are beyond the transect line.

\section{Habitat wise distribution of bird species}

The bird population also showed a great fluctuation within the habitat type. Major eight habitat types were found on the line transect laid down in the Barandabhar forest. Most of the species $(46.48 \%)$ were recorded from Sal-forest followed by open grassland $(22.81 \%)$, Sal-forest/grassland forest (13.21\%), Sal mixed forest $(8.70 \%)$, wetland $(2.88 \%)$, mixed riverine forest $(2.47 \%)$, grassland associated with few Sal trees $(2.02 \%)$ and mixed forest $(1.39 \%)$.

Leptoptilos javanicus(Lesser Adjutant) preferred marshy areas in open grassland. Anhinga melanogaster (Oriental Darter) was only seen in Beeshazari Lake resting on the dead wooden log but forest, shrubland, and grassland birds were abundant in all types of habitats. Metopidius indicus (Bronze-winged Jacana) was the permanent resident bird for Beeshazari Lake. Similarly, Pseudibus papillosa (Black Ibis) was recorded only in the wetlands. The population of Spilopelia chinensis (Spotted Dove)was remarkable in the Barandabhar corridor forest and it was highly dominant in the Sal -forest. Rhino Lake, in the Barandabhar forest, was adorned with Pseudibus papillosa (Black Ibis) and Ardeola grayii (Indian Pond Heron). (Indian Peafowl), Turdoides striates (Jungle Babbler), and Dicrurus macrocercus(Black 
Drongo) were recorded in almost every habitat type. Hieraaetus pennatus (Booted Eagle) and Nisaetus cirrhatus (Changeable Hawk Eagle)were the least recorded found in Shorea robusta (Sal) and grassland habitat. In the Shorea robusta (Sal) near Tikauli, 18 nests of Anastomus oscitans (Asian Openbill) were seen. That location was the new breeding site for the Asian Openbill. Eight species of Woodpeckers were recorded occupying mostly Salforest, grassland, and Sal mix forest. They included Dendrocopos canicapillus (Grey-capped Pygmy Woodpecker), Dendrocopos macei (Fulvous-breasted Woodpecker), Picuschlorolophus (Lesser Yellownape), Picus xanthopygaeus (Streakhroated Woodpecker), Picus canus (Grey-faced Woodpecker), Dinopiumshorri (Himalayan Flameback), Dinopium benghalense (Black-rumped Flameback), and Chrysocolaptes lucidus (Greater Flameback). Woodpeckers are known to be good indicators of forest biodiversity (Ghimire 2009). Similarly, four species of Parakeet such as Psittacula eupatria (Alexandrine Parakeet), Psittacula krameri (Rose-ringed Parakeet), (Plum-headed Parakeet), and Psittacula alexandri(Red-breasted Parakeet) were noticed utilizing mostly Sal-forest. Their population was remarkably high in spring.

\section{Major threats to the bird species}

According to the IUCN Red List of Threatened Species, five species were placed as Near Threatened, one species as Vulnerable, and all remaining (119 species) are placed as Least Concern category. Similarly, following the National Red List of Nepal' Birds and IUCN Regional Red List Categories and Criteria, the total number of 110 species out of 125 species are enlisted as Least Concern, eight species were classified under Near Threatened, six species were placed in the Vulnerable category and one species was placed in the Critically Endangered category (Table 1). One Globally Threatened Bird recorded was Leptoptilos javanicus (Lesser Adjutant).

This study also revealed that fishing, habitat disturbance, and noise pollution by vehicles inside the Barandabhar forest are responsible factors for the disturbances of birds. Due to fishing, fish-dependent birds such as Kingfisher species, Anhinga melanogaster (Oriental Darter), and Ichthyophaga ichthyaetus(Grey-headed Fish Eagle) were immensely affected (Ghimire,2009). Because of the over-growing of alien plant species such as Eichhornia crassipes (Water Hyacinth) and Leersia hexandra (American Cutgrass) the water birds like Fulica atra (Common Coot) were not seen. Beeshazari Lake is in a jeopardized condition due to angler, crocodile hunters, firewood collectors, and edible vegetation collector eg. Dryopteris sp.(Nigro), Bauhinia variegate(Koiralo), and Asparagus sp.(Kurilo).

\section{CONCLUSION}

This study revealed that the Barandabhar Corridor Forest supports a large number of bird species. Some of the species of birds were enlisted as Least Concern, eight species were classified under Near Threatened, six species were placed in the Vulnerable category and one species was placed in the Critically Endangered category. The study also revealed that fishing, habitat disturbance, and noise pollution by vehicles inside the Barandabhar forest are responsible for the disturbances of birds. According to the migratory pattern of birds, Beeshazari Lake need to be regains its pristine state. The diversity of fruiting plants for 
example Bombaxceiba (Simal), Syzigium cumini (Jamun), Zizyphus jujube (Bayer) should be properly maintained. Awareness programs about the conservation of birds should be conducted. In the future, with the improvement in habitat and food availability of Barandabhar Corridor Forest, there will not only be an increment in the number of native birds but it will also attract more migratory birds.

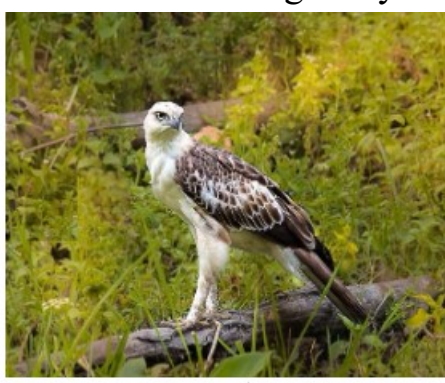

Changeable Hawk Eagle (Spizaetus cirrhatus)

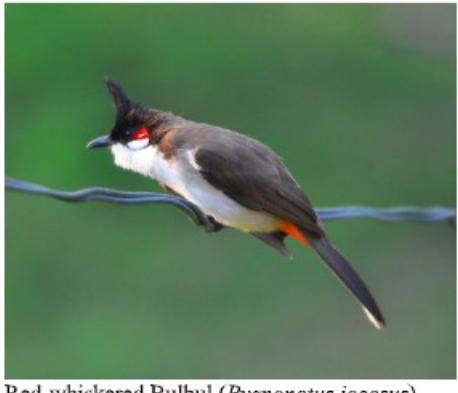

Red-whiskered Bulbul (Pycnonotus jocosus)
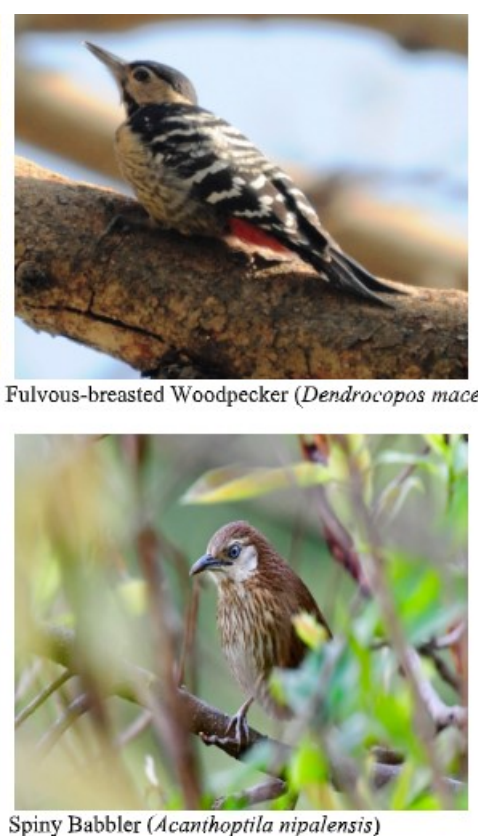

Fig. 5. The collection of photographs observed on study sites

\section{ACKNOWLEDGEMENTS}

I express my sincere thanks to Mr. Tek Bahadur Gurung, Nature guide of Chitwan National Park for his valuable advice and support.

\section{REFERENCES}

Adhikari, J. N., Bhatarai, B. P. \& Thapa, T. B. (2019). Factors affecting diversity and distribution of threatened birds in Chitwan National Park, Nepal. Journal of Threatened 11(5): Taxa 13511-13522. https://doi.org/10.11609/jot.4137.11.5.13511-13522

Adhikari, R., Karmacharya, R., Adhikari, Y. and Sapkota, D. R. (2000).The birds of Barandabhar. (Unpublished report). Bird Education Society, Sauraha.

Adhikari, J. N., Bhattarai, B. P. and Thapa, T. B. (2018). Diversity and conservation threats of waterbirds in and around Barandabhar corridor forest, Chitwan, Nepal. Journal of Natural History Museum, 30, 164-179. https://doi.org/10.3126/jnhm.v30i0.27553

Baral, H. S., and Inskipp, C. (2005). .Important Bird Areas in Nepal: Key Sites for Conservation. Bird Conservation Nepal and Bird Life International, Kathmandu and Cambridge.

Baral, H. S., and Inskipp, C. (2004). The State of Nepal's birds. Department of National Parks and Wildlife Conservation, Bird Conservation Nepal and IUCN Nepal, Kathmandu.

BCN and DNPWC (2018). Birds of Nepal: An Official Checklist. Department of National Parks and Wildlife Conservation, Kathmandu, Nepal.Pp.36. 
Bibi, F., and Z. Ali, (2013). Measurement of diversity indices of avian communities at TaunsaBarrage Wildlife Sanctuary. Pakistan Journal of Animal and Plant Sciences. 23:469-474.

Bird Life International (2020). Country profile: Nepal. Available from www.birdlifenepal.org [Date accessed: 24 January 2021].

Bird Education Society (1999). Bird Checklist of Barandabhar Forest, Sauraha, Chitwan, (Unpublished report).

Buckland, S. T. (2006). Point transect surveys for songbirds: robust methodologies. Auk 123: 345-357.

Dahal, B. R. (2002) Birds, Bird Diversity and Barandabhar Corridor Forest, Danphe 11(1):3637.

Dahal, B. R. (2003). Bird Checklist of Barandabhar Forest Corridor, (Unpublished report) submitted to King Mahendra Trust for Nature Conservation, Jawalakhel, Lalitpur.

DNPWC (1973). National Parks and Wildlife Conservation Act, 1973.Department of National Parks and Wildlife Conservation, Ministry of Forestry and Soil Conservation, Kathmandu, Nepal.

Gale, G. A., Round, P. D., Piece, A. J., Nimnuan, S., Pattanavibool, A. and Brockelman, W. Y. (2009). A field test of distance sampling methods for a tropical forest bird community. Auk 126: 439-448.

Ghimire, B. C., (2009). Avifaunal Survey of Barandabhar Forests and Wetlands IBA, Central Lowland Nepal, Danphe 18(4):1-8.

Grimmett, R., Inskipp, C. and Inskipp, T.(2011). Birds of the Indian Subcontinent $\left(2^{\text {nd }}\right.$ edition). Helms Field Guide, Oxford University Press, India.

Grimmett, R., Inskipp, C., Inskipp, T. and Baral, H. S. (2016). Birds of Nepal Revised edition. Christopher Helms, London UK.

Inskipp, C., Baral, H. S., Phuyal, S., Bhatt, T. R., Khatiwada, M., Inskipp, T., Khatiwada, A. Gurung, S., Singh, P. B., Murray, L., Poudyal, L. and Amin, R. (2016). The Status of Nepal's Birds: The National Red List Series. Zoological Society of London, UK.

Inskipp, C., Baral, H. S., Inskipp, T. , Khaiwada, A. P., Khaiwada, M. P., Poudyal, L. and Amin, R. (2017). Nepal's National Red List of Birds. Journal of Threatened Taxa 9(1): 9700-9722. htps://doi.org/10.11609/jot.2855.9.1.9700-9722

IUCN (2018). The IUCN Red List of Threatened Species. Version 2017-3. Available online at www.iucnredlist.org. [Date accessed: 24 January 2021].

KMTNC (2005).Tiger and Rhino Conservation Project, Status of Birds in the Barandabhar Corridor Forest. Kathmandu, Nepal.

Koli, V. K. (2014). Diversity and status of avifauna in Todgarh-Raoli Wildlife Sanctuary, Rajasthan, India. Journal of Asia-Pacific Biodiversity. 7: 401-407. 
International Research Journal of MMC (IRJMMC)

Vol. 2 Issue 4 (December, 2021)

ISSN 2717-4999 (Online)

2717-4980 (Print)

Mensing, A. (2011, 5 16). http. Retrieved 12 20, 2021, from longnow.org: https://longnow.org/ideas/02011/05/16/around-the-world-in-10000-birds/

Sharma, H. K. (2004). Diversity of threatened birds and their conservation threats in Barandabhar corridor forest, Chitwan. M.Sc. thesis, Central Department of Zoology, Tribhuvan University, Kirtipur, Kathmandu, Nepal.

Singh, D. (2015).AvifaunalDiversity of Hamirpur District, Himachal Pradesh, India. International Journal of Advanced Research, 3(12), pp. 265 - 276.

Sarkar, N. J., Sultana, D., Jaman, M. F. and Rahman, M. K. (2009). Diversity and Population of Avifauna of two urban sites in Dhaka, Bangladesh. Ecoprint 16: 1-7. www.ecosnepal.com.

\section{Appendix-I}

Table 1: Checklist of Birds of Barandabhar Forest

\begin{tabular}{|c|c|c|c|c|c|c|c|}
\hline \multirow[t]{3}{*}{ S.N. } & \multicolumn{7}{|l|}{ Checklist of Birds } \\
\hline & \multicolumn{2}{|c|}{ Order/Family/Common Name/Scientific Name } & \multicolumn{2}{|c|}{ Season } & \multirow{2}{*}{\begin{tabular}{|l|} 
Local \\
Status \\
\end{tabular}} & \multirow{2}{*}{$\begin{array}{l}\text { Global } \\
\text { Status } \\
\end{array}$} & \multirow{2}{*}{$\begin{array}{l}\text { Rel. } \\
\text { Abu }\end{array}$} \\
\hline & & & Autumn & Spring & & & \\
\hline & GALLIFORMES & & & & & & \\
\hline & Phasianidae & & & & & & \\
\hline 1 & Black Francolin & $\begin{array}{|ll|}\begin{array}{l}\text { Francolinus } \\
\text { (Linnaeus, 1766) }\end{array} & \text { francolinus } \\
\end{array}$ & & $x$ & LC & $\mathrm{LC}$ & $\mathrm{C}$ \\
\hline \multirow[t]{3}{*}{2} & Indian Peafowl & Pavocristatus Linnaeus, 1758 & $\times$ & $x$ & NT & $\mathrm{LC}$ & $\mathrm{VC}$ \\
\hline & ANSERIFORMES & & & & & & \\
\hline & Anatidae & & & & & & \\
\hline \multirow[t]{3}{*}{3} & Lesser Whistling-duck & $\begin{array}{l}\text { Dendrocygnajavanica } \\
\text { (Horsfield, 1821) }\end{array}$ & & $x$ & LC & $\mathrm{LC}$ & $\mathrm{C}$ \\
\hline & PICIFORMES & & & & & & \\
\hline & Picidae & & & & & & \\
\hline 4 & Rufous Woodpecker & \begin{tabular}{|l} 
Micropternusbrachyurus \\
(Vieillot, 1818) \\
\end{tabular} & $x$ & $x$ & LC & $\mathrm{LC}$ & $\mathrm{VC}$ \\
\hline 5 & $\begin{array}{l}\text { Fulvous-breasted } \\
\text { Woodpecker }\end{array}$ & $\begin{array}{l}\text { Dendrocoposmacei(Vieillot, } \\
1818 \text { ) }\end{array}$ & $x$ & $x$ & $\mathrm{LC}$ & $\mathrm{LC}$ & $\mathrm{VC}$ \\
\hline 6 & Lesser Yellownape & Picuschlorolophus Vieillot, 1818 & & $x$ & LC & $\mathrm{LC}$ & $\mathrm{C}$ \\
\hline 7 & Greater Yellownape & $\begin{array}{l}\text { Chrysophlegmaflavinucha } \\
\text { (Gould, 1834) }\end{array}$ & & $x$ & LC & $\mathrm{LC}$ & $\mathrm{UC}$ \\
\hline 8 & $\begin{array}{l}\text { Streak-throated } \\
\text { Woodpecker }\end{array}$ & $\begin{array}{|ll|}\text { Picusxanthopygaeus (Gray \& } \\
\text { Gray, 1846) }\end{array}$ & $x$ & $x$ & LC & $\mathrm{LC}$ & $\mathrm{C}$ \\
\hline 9 & $\begin{array}{l}\text { Grey-faced } \\
\text { Woodpecker }\end{array}$ & PicuscanusGmelin, 1788 & $x$ & $x$ & $\mathrm{LC}$ & $\mathrm{LC}$ & $\mathrm{VC}$ \\
\hline 10 & Himalayan Flameback & Dinopiumshorii(Vigors, 1832) & $\times$ & $x$ & $\mathrm{LC}$ & $\mathrm{LC}$ & $\mathrm{VC}$ \\
\hline 11 & Greater Flameback & $\begin{array}{l}\text { Chrysocolapteslucidus (Scopoli, } \\
1786 \text { ) }\end{array}$ & $x$ & $x$ & LC & $\mathrm{LC}$ & $\mathrm{C}$ \\
\hline \multirow[t]{2}{*}{12} & $\begin{array}{l}\text { Black- } \\
\text { rumpedFlameback }\end{array}$ & \begin{tabular}{|l} 
Dinopiumbenghalense(Linnaeus, \\
1758 ) \\
\end{tabular} & $x$ & $x$ & LC & $\mathrm{LC}$ & $\mathrm{VC}$ \\
\hline & Megalaimidae & & & & & & \\
\hline 13 & Lineated Barbet & Psilopogonlineatus & $x$ & $x$ & LC & $\mathrm{LC}$ & $\mathrm{VC}$ \\
\hline
\end{tabular}


International Research Journal of MMC (IRJMMC)

Vol. 2 Issue 4 (December, 2021)

ISSN 2717-4999 (Online)

2717-4980 (Print)

\begin{tabular}{|c|c|c|c|c|c|c|c|}
\hline & & 1816) & & & & & \\
\hline & BUCEROTIFORMES & & & & & & \\
\hline & Bucerotidae & & & & & & \\
\hline \multirow[t]{2}{*}{14} & Oriental Pied Hornbill & $\begin{array}{l}\text { Anthracocerosalbirostris(Shaw } \\
\text { \&Nodder, 1807) }\end{array}$ & & $x$ & NT & $\mathrm{LC}$ & $\mathrm{C}$ \\
\hline & Upupidae & & & & & & \\
\hline \multirow[t]{3}{*}{15} & Common Hoopoe & UpupaepopsLinnaeus, 1758 & $x$ & $x$ & $\mathrm{LC}$ & $\mathrm{LC}$ & $\mathrm{C}$ \\
\hline & CORACIIFORMES & & & & & & \\
\hline & Coraciidae & & & & & & \\
\hline 16 & Oriental Dollarbird & $\begin{array}{l}\text { Eurystomusorientalis(Linnaeus, } \\
1766 \text { ) }\end{array}$ & & $x$ & $\mathrm{LC}$ & $\mathrm{LC}$ & $\mathrm{C}$ \\
\hline \multirow[t]{2}{*}{17} & Indian Roller & $\begin{array}{l}\text { Coraciasbenghalensis } \\
\text { (Linnaeus, 1758) }\end{array}$ & $\bar{x}$ & $x$ & $\mathrm{LC}$ & $\mathrm{LC}$ & $\mathrm{VC}$ \\
\hline & Alcedinidae & & & & & & \\
\hline 18 & Common Kingfisher & Alcedoatthis(Linnaeus, 1758) & $\times$ & & $\mathrm{LC}$ & $\mathrm{LC}$ & $\mathrm{VC}$ \\
\hline 19 & Stork-billed Kingfisher & $\begin{array}{l}\text { Pelargopsiscapensis (Linnaeus, } \\
1766 \text { ) }\end{array}$ & & $x$ & $\mathrm{LC}$ & $\mathrm{LC}$ & $\mathrm{VC}$ \\
\hline 20 & $\begin{array}{l}\text { White-throated } \\
\text { Kingfisher }\end{array}$ & Halcyon gularis(Kuhl, 1820) & $\bar{x}$ & $x$ & $\mathrm{LC}$ & $\mathrm{LC}$ & $\mathrm{VC}$ \\
\hline \multirow[t]{2}{*}{21} & Pied Kingfisher & Cerylerudis(Linnaeus, 1758) & & $x$ & $\mathrm{LC}$ & $\mathrm{LC}$ & $\mathrm{C}$ \\
\hline & Meropidae & & & & & & \\
\hline 22 & $\begin{array}{l}\text { Chestnut-headed Bee- } \\
\text { eater }\end{array}$ & $\begin{array}{l}\text { MeropsleschenaultiVieillot, } \\
1817\end{array}$ & & $x$ & $\mathrm{LC}$ & $\mathrm{LC}$ & $\mathrm{VC}$ \\
\hline \multirow[t]{3}{*}{23} & Green Bee-eater & MeropsorientalisLatham, 1802 & $x$ & $x$ & $\mathrm{LC}$ & $\mathrm{LC}$ & $\mathrm{C}$ \\
\hline & CUCULIFORMES & & & & & & \\
\hline & Cuculidae & & & & & & \\
\hline 24 & Indian Cuckoo & CuculusmicropterusGould, 1837 & $\bar{x}$ & $x$ & $\mathrm{LC}$ & $\mathrm{LC}$ & $\mathrm{VC}$ \\
\hline 25 & Common Cuckoo & CuculuscanorusLinnaeus, 1758 & $x$ & $x$ & $\mathrm{LC}$ & $\mathrm{LC}$ & $\mathrm{UC}$ \\
\hline 26 & $\begin{array}{l}\text { Square-tailed Drongo- } \\
\text { cuckoo }\end{array}$ & $\begin{array}{l}\text { Surniculuslugubris(Horsfield, } \\
\text { 1821) }\end{array}$ & $\bar{x}$ & $x$ & $\mathrm{LC}$ & $\mathrm{LC}$ & $\mathrm{C}$ \\
\hline 27 & $\begin{array}{ll}\text { Common } & \text { Hawk } \\
\text { Cuckoo } & \\
\end{array}$ & Hierococcyxvarius (Vahl, 1797) & $\times$ & $x$ & $\mathrm{LC}$ & $\mathrm{LC}$ & $\mathrm{VC}$ \\
\hline 28 & Asian Koel & $\begin{array}{l}\text { Eudynamysscolopaceus } \\
\text { (Linnaeus, 1758) }\end{array}$ & & $x$ & $\mathrm{LC}$ & $\mathrm{LC}$ & $\mathrm{VC}$ \\
\hline 29 & Green-billed Malkoha & $\begin{array}{l}\text { Phaenicophaeustristis (Lesson, } \\
\text { 1830) }\end{array}$ & $\bar{x}$ & $x$ & $\mathrm{LC}$ & $\mathrm{LC}$ & $\mathrm{C}$ \\
\hline 30 & Greater Coucal & $\begin{array}{l}\text { Centropussinensis(Stephens, } \\
\text { 1815) }\end{array}$ & $x$ & $x$ & $\mathrm{LC}$ & $\mathrm{LC}$ & $\mathrm{VC}$ \\
\hline \multirow[t]{3}{*}{31} & Lesser Coucal & $\begin{array}{l}\text { Centropusbengalensis(Gmelin, } \\
1788)\end{array}$ & & $x$ & $\mathrm{LC}$ & $\mathrm{LC}$ & $\mathrm{C}$ \\
\hline & PSITTACIFORMES & & & & & & \\
\hline & Psittacidae & & & & & & \\
\hline 32 & Alexandrine Parakeet & $\begin{array}{l}\text { Psittaculaeupatria(Linnaeus, } \\
1766 \text { ) }\end{array}$ & $x$ & $x$ & NT & NT & $\mathrm{VC}$ \\
\hline 33 & Slaty-headed Parakeet & $\begin{array}{l}\text { Himalayapsittahimalayana } \\
\text { (Lesson, 1832) }\end{array}$ & $\bar{x}$ & $x$ & $\mathrm{LC}$ & $\mathrm{LC}$ & $\mathrm{VC}$ \\
\hline 34 & Plum-headed Parakeet & Psittaculacyanocephala(Linnaeu & $\times$ & $x$ & $\mathrm{LC}$ & $\mathrm{LC}$ & $\mathrm{VC}$ \\
\hline
\end{tabular}


International Research Journal of MMC (IRJMMC)

Vol. 2 Issue 4 (December, 2021)

ISSN 2717-4999 (Online)

2717-4980 (Print)

\begin{tabular}{|c|c|c|c|c|c|c|c|}
\hline & & s, 1766) & & & & & \\
\hline \multirow[t]{3}{*}{35} & Red-breasted Parakeet & $\begin{array}{l}\text { Psittaculaalexandri (Linnaeus, } \\
1758 \text { ) }\end{array}$ & $\times$ & $x$ & VU & NT & $\mathrm{C}$ \\
\hline & $\begin{array}{l}\text { CAPRIMULGIFOR } \\
\text { MES }\end{array}$ & & & & & & \\
\hline & Apodidae & & & & & & \\
\hline \multirow[t]{3}{*}{36} & $\begin{array}{l}\text { Silver-backed } \\
\text { Needletail }\end{array}$ & $\begin{array}{l}\text { Hirundapuscochinchinensis } \\
\text { (Oustalet, 1878) }\end{array}$ & & $x$ & $\mathrm{LC}$ & $\mathrm{LC}$ & $\mathrm{R}$ \\
\hline & STRIGIFORMES & & & & & & \\
\hline & Strigidae & & & & & & \\
\hline 37 & Jungle Owlet & $\begin{array}{l}\text { Glaucidiumradiatum(Tickell, } \\
\text { 1833) }\end{array}$ & & $x$ & $\mathrm{LC}$ & $\mathrm{LC}$ & $\mathrm{VC}$ \\
\hline \multirow[t]{3}{*}{38} & Asian Barred Owlet & $\begin{array}{l}\text { Glaucidiumcuculoides(Vigors, } \\
\text { 1831) }\end{array}$ & & $x$ & $\mathrm{LC}$ & $\mathrm{LC}$ & $\mathrm{R}$ \\
\hline & COLUMBIFORMES & & & & & & \\
\hline & Columbidae & & & & & & \\
\hline 39 & $\begin{array}{l}\text { Yellow-footed Green- } \\
\text { pigeon }\end{array}$ & $\begin{array}{l}\text { Treronphoenicopterus(Latham, } \\
1790 \text { ) }\end{array}$ & & $x$ & $\mathrm{LC}$ & $\mathrm{LC}$ & $\mathrm{VC}$ \\
\hline 40 & Spotted Dove & $\begin{array}{l}\text { Spilopeliachinensis(Scopoli, } \\
1786)\end{array}$ & $x$ & $x$ & $\mathrm{LC}$ & $\mathrm{LC}$ & $\mathrm{VC}$ \\
\hline 41 & Eurasian Collared-dove & $\begin{array}{l}\text { StreptopeliadecaoctoFrivaldszky } \\
, 1838\end{array}$ & $x$ & $x$ & $\mathrm{LC}$ & $\mathrm{LC}$ & $\mathrm{VC}$ \\
\hline 42 & Emerald Dove & $\begin{array}{l}\text { Chalcophapsindica(Linnaeus, } \\
1758)\end{array}$ & $x$ & $x$ & $\mathrm{LC}$ & $\mathrm{LC}$ & $\mathrm{C}$ \\
\hline \multirow[t]{3}{*}{43} & Red Collared Dove & $\begin{array}{l}\text { Streptopeliatranquebarica } \\
\text { (Hermann, 1804) }\end{array}$ & $\times$ & $x$ & $\mathrm{LC}$ & $\mathrm{LC}$ & $\mathrm{C}$ \\
\hline & GRUIFORMES & & & & & & \\
\hline & Rallidae & & & & & & \\
\hline \multirow[t]{3}{*}{44} & $\begin{array}{l}\text { White-breasted } \\
\text { Waterhen }\end{array}$ & $\begin{array}{l}\text { Amaurornisphoenicurus(Pennant } \\
\text {,1769) }\end{array}$ & & $x$ & $\mathrm{LC}$ & $\mathrm{LC}$ & $\mathrm{VC}$ \\
\hline & $\begin{array}{l}\text { CHARADRIIFORME } \\
\text { S }\end{array}$ & & & & & & \\
\hline & Scolopacidae & & & & & & \\
\hline 45 & Common Greenshank & $\begin{array}{l}\text { Tringanebularia(Gunnerus, } \\
1767)\end{array}$ & $\times$ & $\times$ & $\mathrm{LC}$ & $\mathrm{LC}$ & $\mathrm{VC}$ \\
\hline 46 & Green Sandpiper & TringaochropusLinnaeus, 1758 & $\times$ & $\times$ & $\mathrm{LC}$ & $\mathrm{LC}$ & $\mathrm{VC}$ \\
\hline \multirow[t]{2}{*}{47} & Common Sandpiper & $\begin{array}{l}\text { ActitishypoleucosLinnaeus, } \\
1758\end{array}$ & $\times$ & $x$ & $\mathrm{LC}$ & $\mathrm{LC}$ & $\mathrm{VC}$ \\
\hline & Jacanidae & & & & & & \\
\hline \multirow[t]{2}{*}{48} & Bronze-winged Jacana & $\begin{array}{l}\text { Metopidiusindicus(Latham, } \\
1790)\end{array}$ & $x$ & $x$ & $\mathrm{LC}$ & $\mathrm{LC}$ & $\mathrm{C}$ \\
\hline & Burhinidae & & & & & & \\
\hline \multirow[t]{2}{*}{49} & Eurasian Thick-knee & $\begin{array}{l}\text { Burhinusoedicnemus (Linnaeus, } \\
1758 \text { ) }\end{array}$ & & $x$ & $\mathrm{LC}$ & $\mathrm{LC}$ & $\mathrm{UC}$ \\
\hline & Charadriidae & & & & & & \\
\hline 50 & Little Ringed Plover & CharadriusdubiusScopoli, 1786 & & $x$ & $\mathrm{LC}$ & $\mathrm{LC}$ & $\mathrm{VC}$ \\
\hline 51 & Red-wattled Lapwing & $\begin{array}{l}\text { Vanellusindicus(Boddaert, } \\
1783 \text { ) }\end{array}$ & $x$ & $x$ & $\mathrm{LC}$ & $\mathrm{LC}$ & $\mathrm{VC}$ \\
\hline
\end{tabular}


International Research Journal of MMC (IRJMMC)

Vol. 2 Issue 4 (December, 2021)

ISSN 2717-4999 (Online)

2717-4980 (Print)

\begin{tabular}{|c|c|c|c|c|c|c|c|}
\hline & ACCIPITRIFORMES & & & & & & \\
\hline & Pandionidae & & & & & & \\
\hline \multirow[t]{2}{*}{52} & Osprey & $\begin{array}{l}\text { Pandionhaliaetus(Linnaeus, } \\
1758 \text { ) }\end{array}$ & & $x$ & $\mathrm{LC}$ & $\mathrm{LC}$ & $\mathrm{C}$ \\
\hline & Accipitridae & & & & & & \\
\hline 53 & Black Baza & $\begin{array}{l}\text { Avicedaleuphotes(Dumont, } \\
1820 \text { ) }\end{array}$ & $\bar{x}$ & $x$ & NT & $\mathrm{LC}$ & $\mathrm{UC}$ \\
\hline 54 & $\begin{array}{l}\begin{array}{l}\text { Grey-headed } \\
\text { Eeagle }\end{array} \\
\text { Fish } \\
\end{array}$ & $\begin{array}{l}\text { Ichthyophagaichthyaetus(Horsfie } \\
\text { ld, 1821) }\end{array}$ & $\bar{x}$ & & $\mathrm{CR}$ & NT & $\mathrm{UC}$ \\
\hline 55 & $\begin{array}{ll}\begin{array}{l}\text { Changeable Hawk } \\
\text { Eagle }\end{array} & \\
\end{array}$ & $\begin{array}{l}\text { Nisaetuscirrhatus(Gmelin, } \\
\text { 1788) }\end{array}$ & $\bar{x}$ & $x$ & $\mathrm{LC}$ & $\mathrm{LC}$ & $\mathrm{UC}$ \\
\hline 56 & Shikra & Accipiter badius(Gmelin, 1788) & $x$ & $x$ & $\mathrm{LC}$ & $\mathrm{LC}$ & $\mathrm{C}$ \\
\hline \multirow[t]{3}{*}{57} & Booted Eagle & $\begin{array}{l}\text { Hieraaetuspennatus(Gmelin, } \\
1788 \text { ) }\end{array}$ & $\bar{x}$ & & $\mathrm{LC}$ & $\mathrm{LC}$ & $\mathrm{R}$ \\
\hline & FALCONIFORMES & & & & & & \\
\hline & Falconidae & & & & & & \\
\hline \multirow[t]{3}{*}{58} & Collared Falconet & $\begin{array}{l}\text { Microhieraxcaerulescens } \\
\text { (Linnaeus, } 1758\end{array}$ & $\bar{x}$ & & NT & $\mathrm{LC}$ & $\mathrm{UC}$ \\
\hline & SULIFORMES & & & & & & \\
\hline & Anhingidae & & & & & & \\
\hline \multirow[t]{3}{*}{59} & Oriental Darter & $\begin{array}{l}\text { Anhinga melanogaster Pennant, } \\
1769\end{array}$ & & $x$ & NT & NT & $\mathrm{C}$ \\
\hline & PELECANIFORMES & & & & & & \\
\hline & Ardeidae & & & & & & \\
\hline 60 & Little Egret & $\begin{array}{l}\text { Egrettagarzetta(Linnaeus, } \\
1766)\end{array}$ & $\bar{x}$ & $x$ & $\mathrm{LC}$ & $\mathrm{LC}$ & $\mathrm{VC}$ \\
\hline 61 & Indian Pond Heron & Ardeolagrayii(Sykes, 1832) & $x$ & $x$ & $\mathrm{LC}$ & $\mathrm{LC}$ & $\mathrm{VC}$ \\
\hline 62 & Great White Egret & Ardea alba Linnaeus, 1758 & $x$ & $x$ & $\mathrm{LC}$ & $\mathrm{LC}$ & $\mathrm{C}$ \\
\hline 63 & Intermediate Egret & ArdeaintermediaWagler, 1829 & $x$ & $x$ & $\mathrm{LC}$ & $\mathrm{LC}$ & $\mathrm{C}$ \\
\hline \multirow[t]{2}{*}{64} & Cattle Egret & Bubulcus ibis (Linnaeus, 1758) & $x$ & & $\mathrm{LC}$ & $\mathrm{LC}$ & $\mathrm{VC}$ \\
\hline & Threskiornithidae & & & & & & \\
\hline \multirow[t]{3}{*}{65} & Red-naped Ibis & $\begin{array}{l}\text { Pseudibispapillosa (Temminck, } \\
1824 \text { ) }\end{array}$ & $\bar{x}$ & $x$ & $\mathrm{LC}$ & $\mathrm{LC}$ & $\mathrm{C}$ \\
\hline & CICONIIFORMES & & & & & & \\
\hline & Ciconiidae & & & & & & \\
\hline 66 & Asian Openbill & $\begin{array}{l}\text { Anastomusoscitans (Boddaert, } \\
\text { 1783) }\end{array}$ & $x$ & $x$ & VU & $\mathrm{LC}$ & $\mathrm{C}$ \\
\hline 67 & Asian Woollyneck & $\begin{array}{l}\text { Ciconiaepiscopus(Boddaert, } \\
1783 \text { ) }\end{array}$ & & $x$ & NT & NT & $\mathrm{C}$ \\
\hline 68 & Lesser Adjutant & $\begin{array}{l}\text { Leptoptilosjavanicus(Horsfield, } \\
1821 \text { ) }\end{array}$ & $x$ & $x$ & VU & VU & $\mathrm{C}$ \\
\hline \multirow[t]{3}{*}{69} & Black Stork & Ciconianigra(Linnaeus, 1758) & $x$ & $x$ & VU & $\mathrm{LC}$ & $\mathrm{C}$ \\
\hline & PASSERIFORMES & & & & & & \\
\hline & Pittidae & & & & & & \\
\hline 70 & Hooded Pitta & Pitta sordida(Müller, 1776) & & $x$ & VU & $\mathrm{LC}$ & $\mathrm{C}$ \\
\hline 71 & Indian Pitta & Pitta brachyura(Linnaeus, & & $x$ & $\mathrm{LC}$ & $\mathrm{LC}$ & $\mathrm{C}$ \\
\hline
\end{tabular}


International Research Journal of MMC (IRJMMC)

Vol. 2 Issue 4 (December, 2021)

ISSN 2717-4999 (Online)

2717-4980 (Print)

\begin{tabular}{|c|c|c|c|c|c|c|c|}
\hline & & 1766) & & & & & \\
\hline & Chloropseidae & & & & & & \\
\hline \multirow[t]{2}{*}{72} & $\begin{array}{ll}\text { Golden-fronted Leaf } \\
\text { bird }\end{array}$ & $\begin{array}{l}\text { Chloropsisaurifrons } \\
\text { (Temminck, 1829) }\end{array}$ & & $x$ & $\mathrm{LC}$ & $\mathrm{LC}$ & $\mathrm{C}$ \\
\hline & Laniidae & & & & & & \\
\hline 73 & Long-tailed Shrike & LaniusschachLinnaeus, 1758 & $\bar{x}$ & $x$ & $\mathrm{LC}$ & $\mathrm{LC}$ & $\mathrm{R}$ \\
\hline \multirow[t]{2}{*}{74} & Grey-backed Shrike & $\begin{array}{l}\text { Laniustephronotus(Vigors, } \\
1831 \text { ) }\end{array}$ & $\bar{x}$ & $x$ & $\mathrm{LC}$ & $\mathrm{LC}$ & $\mathrm{R}$ \\
\hline & Corvidae & & & & & & \\
\hline 75 & Red-billed Blue Magpie & $\begin{array}{l}\text { Urocissaerythroryncha(Boddaert } \\
\text {, 1783) }\end{array}$ & $\bar{x}$ & $\bar{x}$ & $\mathrm{LC}$ & $\mathrm{LC}$ & $\mathrm{C}$ \\
\hline 76 & RufousTreepie & $\begin{array}{l}\text { Dendrocittavagabunda(Latham, } \\
1790 \text { ) }\end{array}$ & $\bar{x}$ & $\bar{x}$ & $\mathrm{LC}$ & $\mathrm{LC}$ & $\mathrm{VC}$ \\
\hline 77 & House Crow & Corvussplendens Vieillot, 1817 & $\bar{x}$ & $x$ & $\mathrm{LC}$ & $\mathrm{LC}$ & $\mathrm{UC}$ \\
\hline \multirow[t]{2}{*}{78} & Large-billed Crow & $\begin{array}{l}\text { Corvusmacrorhynchos Wagler, } \\
1827\end{array}$ & $\bar{x}$ & $x$ & $\mathrm{LC}$ & $\mathrm{LC}$ & $\mathrm{VC}$ \\
\hline & Artamidae & & & & & & \\
\hline \multirow[t]{2}{*}{79} & Ashy Woodswallow & Artamusfuscus Wagler, 1827 & $\bar{x}$ & $x$ & $\mathrm{LC}$ & $\mathrm{LC}$ & $\mathrm{C}$ \\
\hline & Oriolidae & & & & & & \\
\hline 80 & Eurasian Golden Oriole & Oriolusoriolus(Linnaeus, 1758) & $\times$ & $x$ & $\mathrm{LC}$ & $\mathrm{LC}$ & $\mathrm{VC}$ \\
\hline \multirow[t]{2}{*}{81} & Black-hooded Oriole & $\begin{array}{l}\text { Oriolusxanthornus(Linnaeus, } \\
1758\end{array}$ & $\bar{x}$ & & $\mathrm{LC}$ & $\mathrm{LC}$ & $\mathrm{VC}$ \\
\hline & Campephagidae & & & & & & \\
\hline 82 & Scarlet Minivet & $\begin{array}{l}\text { Pericrocotusflammeus(Forster, } \\
1781 \text { ) }\end{array}$ & $\bar{x}$ & $x$ & $\mathrm{LC}$ & $\mathrm{LC}$ & $\mathrm{VC}$ \\
\hline \multirow[t]{2}{*}{83} & Large Cuckooshrike & $\begin{array}{l}\text { Coracinajavensis(Horsfield, } \\
\text { 1821) }\end{array}$ & $x$ & $\bar{x}$ & $\mathrm{LC}$ & $\mathrm{LC}$ & $\mathrm{VC}$ \\
\hline & Rhipiduridae & & & & & & \\
\hline \multirow[t]{2}{*}{84} & White-throated Fantail & $\begin{array}{l}\text { Rhipiduraalbicollis(Vieillot, } \\
\text { 1818) }\end{array}$ & $\bar{x}$ & $x$ & $\mathrm{LC}$ & $\mathrm{LC}$ & $\mathrm{C}$ \\
\hline & Dicruridae & & & & & & \\
\hline 85 & Black Drongo & $\begin{array}{l}\text { DicrurusmacrocercusVieillot, } \\
1817\end{array}$ & $\bar{x}$ & $x$ & $\mathrm{LC}$ & $\mathrm{LC}$ & $\mathrm{VC}$ \\
\hline 86 & Spangled Drongo & $\begin{array}{l}\text { Dicrurusbracteatus (Gould, } \\
\text { 1842) }\end{array}$ & $x$ & $x$ & $\mathrm{LC}$ & $\mathrm{LC}$ & $\mathrm{VC}$ \\
\hline \multirow[t]{2}{*}{87} & Crow-billed Drongo & $\begin{array}{l}\text { Dicrurusannectens(Hodgson, } \\
1836 \text { ) }\end{array}$ & & $\bar{x}$ & $\mathrm{LC}$ & $\mathrm{LC}$ & $\mathrm{R}$ \\
\hline & Aegithinidae & & & & & & \\
\hline \multirow[t]{2}{*}{88} & Common Iora & Aegithinatiphia(Linnaeus, 1758) & $\bar{x}$ & $x$ & $\mathrm{LC}$ & $\mathrm{LC}$ & $\mathrm{VC}$ \\
\hline & Vangidae & & & & & & \\
\hline \multirow[t]{2}{*}{89} & Common Woodshrike & $\begin{array}{l}\text { Tephrodornispondicerianus } \\
\text { (Gmelin, 1789) }\end{array}$ & $x$ & $x$ & $\mathrm{LC}$ & $\mathrm{LC}$ & $\mathrm{C}$ \\
\hline & Monarchidae & & & & & & \\
\hline \multirow[t]{2}{*}{90} & $\begin{array}{ll}\text { Indian } & \text { Paradise- } \\
\text { flycatcher } & \\
\end{array}$ & $\begin{array}{l}\text { Terpsiphoneparadisi (Linnaeus, } \\
1758 \text { ) }\end{array}$ & & $x$ & $\mathrm{LC}$ & $\mathrm{LC}$ & $\mathrm{VC}$ \\
\hline & Muscicapidae & & & & & & \\
\hline 91 & Pale-chinned Flycatcher & Cyornispoliogenys Brooks, 1879 & $\bar{x}$ & $x$ & $\mathrm{LC}$ & $\mathrm{LC}$ & $\mathrm{VC}$ \\
\hline
\end{tabular}

www.mmchetauda.edu.np 
International Research Journal of MMC (IRJMMC)

Vol. 2 Issue 4 (December, 2021)

ISSN 2717-4999 (Online)

2717-4980 (Print)

\begin{tabular}{|c|c|c|c|c|c|c|c|}
\hline 92 & Oriental Magpie-robin & $\begin{array}{l}\text { Copsychussaularis(Linnaeus, } \\
1758 \text { ) }\end{array}$ & $x$ & $\times$ & $\mathrm{LC}$ & $\mathrm{LC}$ & $\mathrm{VC}$ \\
\hline \multirow[t]{2}{*}{93} & White-rumpedShama & $\begin{array}{l}\text { Kittacinclamalabarica (Scopoli, } \\
\text { 1788) }\end{array}$ & & $x$ & $\mathrm{LC}$ & $\mathrm{LC}$ & $\mathrm{VC}$ \\
\hline & Stenostiridae & & & & & & \\
\hline \multirow[t]{2}{*}{94} & $\begin{array}{l}\text { Grey-headed Canary- } \\
\text { flycatcher }\end{array}$ & $\begin{array}{l}\text { Culicicapaceylonensis } \\
\text { (Swainson, 1820) }\end{array}$ & $\bar{x}$ & & $\mathrm{LC}$ & $\mathrm{LC}$ & $\mathrm{C}$ \\
\hline & Sturnidae & & & & & & \\
\hline 95 & Chestnut-tailed Starling & $\begin{array}{l}\text { Sturniamalabarica (Gmelin, } \\
1789 \text { ) }\end{array}$ & & $x$ & $\mathrm{LC}$ & $\mathrm{LC}$ & $\mathrm{VC}$ \\
\hline 96 & Asian Pied Starling & $\begin{array}{l}\text { Gracupica contra (Linnaeus, } \\
1758\end{array}$ & $\bar{x}$ & $x$ & $\mathrm{LC}$ & $\mathrm{LC}$ & $\mathrm{C}$ \\
\hline 97 & Common Myna & $\begin{array}{l}\text { Acridotherestristis(Linnaeus, } \\
\text { 1766) }\end{array}$ & $x$ & $\times$ & $\mathrm{LC}$ & $\mathrm{LC}$ & $\mathrm{UC}$ \\
\hline \multirow[t]{2}{*}{98} & Jungle Myna & $\begin{array}{l}\text { Acridotheresfuscus(Wagler, } \\
\text { 1827) }\end{array}$ & $\bar{x}$ & $x$ & $\mathrm{LC}$ & $\mathrm{LC}$ & $\mathrm{VC}$ \\
\hline & Sittidae & & & & & & \\
\hline 99 & $\begin{array}{l}\text { Chestnut-bellied } \\
\text { Nuthatch }\end{array}$ & Sittacinnamoventris Blyth, 1842 & $\bar{x}$ & $x$ & $\mathrm{LC}$ & $\mathrm{LC}$ & $\mathrm{VC}$ \\
\hline \multirow[t]{2}{*}{100} & $\begin{array}{l}\text { Velvet-fronted } \\
\text { Nuthatch } \\
\end{array}$ & SittafrontalisSwainson, 1820 & & & $\mathrm{LC}$ & $\mathrm{LC}$ & $\mathrm{VC}$ \\
\hline & Paridae & & & & & & \\
\hline \multirow[t]{2}{*}{101} & Great Tit & Parus major Linnaeus, 1758 & $x$ & $\times$ & $\mathrm{LC}$ & $\mathrm{LC}$ & $\mathrm{VC}$ \\
\hline & Hirundinidae & & & & & & \\
\hline 102 & African Plain Martin & $\begin{array}{l}\text { Ripariapaludicola(Vieillot, } \\
\text { 1817) }\end{array}$ & $x$ & $x$ & $\mathrm{LC}$ & $\mathrm{LC}$ & $\mathrm{VC}$ \\
\hline 103 & Barn Swallow & Hirundorustica Linnaeus, 1758 & $x$ & $\times$ & $\mathrm{LC}$ & $\mathrm{LC}$ & $\mathrm{C}$ \\
\hline \multirow[t]{2}{*}{104} & Red-rumped Swallow & $\begin{array}{ll}\text { Cecropisdaurica } & \text { Linnaeus, } \\
1771 & \\
\end{array}$ & $x$ & $\times$ & $\mathrm{LC}$ & $\mathrm{LC}$ & $\mathrm{UC}$ \\
\hline & Pycononotidae & & & & & & \\
\hline 105 & Red-whiskered Bulbul & $\begin{array}{l}\text { Pycnonotusjocosus(Linnaeus, } \\
1758 \text { ) }\end{array}$ & $x$ & $\times$ & $\mathrm{LC}$ & $\mathrm{LC}$ & $\mathrm{VC}$ \\
\hline \multirow[t]{2}{*}{106} & Red-vented Bulbul & $\begin{array}{l}\text { Pycnonotuscafer(Linnaeus, } \\
1766 \text { ) }\end{array}$ & $x$ & $x$ & $\mathrm{LC}$ & $\mathrm{LC}$ & $\mathrm{VC}$ \\
\hline & Cisticolidae & & & & & & \\
\hline 107 & ZittingCisticola & $\begin{array}{l}\text { Cisticolajuncidis(Rafinesque, } \\
1810 \text { ) }\end{array}$ & & $\times$ & $\mathrm{LC}$ & $\mathrm{LC}$ & $\mathrm{VC}$ \\
\hline \multirow[t]{2}{*}{108} & Common Tailorbird & $\begin{array}{l}\text { Orthotomussutorius(Pennant, } \\
\text { 1769) }\end{array}$ & & $\times$ & $\mathrm{LC}$ & $\mathrm{LC}$ & $\mathrm{VC}$ \\
\hline & Locustellidae & & & & & & \\
\hline \multirow[t]{2}{*}{109} & $\begin{array}{ll}\begin{array}{l}\text { Spotted } \\
\text { warbler }\end{array} & \text { Grasshopper- } \\
\end{array}$ & $\begin{array}{l}\text { Locustellathoracica (Blyth, } \\
\text { 1845) }\end{array}$ & & $x$ & $\mathrm{LC}$ & $\mathrm{LC}$ & $\mathrm{R}$ \\
\hline & Acrocephalidae & & & & & & \\
\hline \multirow[t]{2}{*}{110} & Thick-billed Warbler & Arundinaxaedon (Pallas, 1776) & & $\times$ & $\mathrm{LC}$ & $\mathrm{LC}$ & $\mathrm{R}$ \\
\hline & Phylloscopidae & & & & & & \\
\hline \multirow[t]{2}{*}{111} & Greenish Warbler & $\begin{array}{l}\text { Phylloscopustrochiloides } \\
\text { (Sundevall, 1837) }\end{array}$ & & $\times$ & $\mathrm{LC}$ & $\mathrm{LC}$ & $\mathrm{VC}$ \\
\hline & Leiotrichidae & & & & & & \\
\hline
\end{tabular}


International Research Journal of MMC (IRJMMC)

Vol. 2 Issue 4 (December, 2021)

ISSN 2717-4999 (Online)

2717-4980 (Print)

\begin{tabular}{|c|c|c|c|c|c|c|c|}
\hline 112 & Common Babbler & Argyacaudata (Dumont, 1823) & & & VU & $\mathrm{LC}$ & $\mathrm{C}$ \\
\hline \multirow[t]{2}{*}{113} & Spiny Babbler & $\begin{array}{l}\text { Acanthoptilanipalensis } \\
\text { (Hodgson, 1836) }\end{array}$ & & $\times$ & $\mathrm{LC}$ & $\mathrm{LC}$ & $\mathrm{UC}$ \\
\hline & Pellorneidae & & & & & & \\
\hline \multirow[t]{2}{*}{114} & Puff-throated Babbler & $\begin{array}{l}\text { PellorneumruficepsSwainson, } \\
1832\end{array}$ & & $x$ & $\mathrm{LC}$ & $\mathrm{LC}$ & $\mathrm{VC}$ \\
\hline & Pnoepygidae & & & & & & \\
\hline \multirow[t]{2}{*}{115} & Pygmy Wren Babbler & $\begin{array}{l}\text { Pnoepygapusilla } \quad \text { Hodgson, } \\
1845\end{array}$ & $x$ & $x$ & $\mathrm{LC}$ & $\mathrm{LC}$ & $\mathrm{R}$ \\
\hline & Timaliidae & & & & & & \\
\hline \multirow[t]{2}{*}{116} & Pin Striped Tit-babbler & $\begin{array}{l}\text { Mixornisgularis } \quad \text { (Horsfield, } \\
1822 \text { ) }\end{array}$ & $x$ & $x$ & $\mathrm{LC}$ & $\mathrm{LC}$ & $\mathrm{VC}$ \\
\hline & Leiotrichidae & & & & & & \\
\hline \multirow[t]{2}{*}{117} & Jungle Babbler & Turdoidesstriata(Dumont, 1823) & & $x$ & $\mathrm{LC}$ & $\mathrm{LC}$ & $\mathrm{VC}$ \\
\hline & Phylloscopidae & & & & & & \\
\hline \multirow[t]{2}{*}{118} & Common Chiffchaff & $\begin{array}{l}\text { Phylloscopuscollybita (Vieillot, } \\
\text { 1817) }\end{array}$ & & $x$ & $\mathrm{LC}$ & $\mathrm{LC}$ & $\mathrm{UC}$ \\
\hline & Turdidae & & & & & & \\
\hline \multirow[t]{2}{*}{119} & Scaly Thrush & Zootheradauma(Latham, 1790) & $x$ & $x$ & $\mathrm{LC}$ & $\mathrm{LC}$ & $\mathrm{UC}$ \\
\hline & Nectariniidae & & & & & & \\
\hline \multirow[t]{2}{*}{120} & Crimson Sunbird & $\begin{array}{l}\text { Anthopygasiparaja (Raffles, } \\
\text { 1822) }\end{array}$ & & $x$ & $\mathrm{LC}$ & $\mathrm{LC}$ & $\mathrm{UC}$ \\
\hline & Passeridae & & & & & & \\
\hline 121 & House Sparrow & $\begin{array}{l}\text { Passer domesticus (Linnaeus, } \\
1758)\end{array}$ & $x$ & $x$ & $\mathrm{LC}$ & $\mathrm{LC}$ & $\mathrm{UC}$ \\
\hline \multirow[t]{2}{*}{122} & $\begin{array}{l}\text { Chestnut-shouldered } \\
\text { Bush-sparrow }\end{array}$ & $\begin{array}{l}\text { Gymnorisxanthocollis (Burton, } \\
1838 \text { ) }\end{array}$ & $x$ & $x$ & $\mathrm{LC}$ & $\mathrm{LC}$ & $\mathrm{UC}$ \\
\hline & Motacillidae & & & & & & \\
\hline 123 & Paddyfield Pipit & AnthusrufulusVieillot, 1818 & & $x$ & $\mathrm{LC}$ & $\mathrm{LC}$ & $\mathrm{VC}$ \\
\hline \multirow[t]{2}{*}{124} & White-browed Wagtail & $\begin{array}{l}\text { MotacillamaderaspatensisGmeli } \\
\mathrm{n}, 1789\end{array}$ & $\times$ & & $\mathrm{LC}$ & $\mathrm{LC}$ & $\mathrm{C}$ \\
\hline & Ploceidae & & & & & & \\
\hline 125 & Baya Weaver & $\begin{array}{l}\text { Ploceusphilippinus } \text { (Linnaeus, } \\
1766)\end{array}$ & & $x$ & NT & $\mathrm{LC}$ & $\mathrm{C}$ \\
\hline
\end{tabular}

\section{Abbreviation:}

NT-near threatened,

LC-least concerned,

VU-vulnerable,

CR-critically endangered,

$\mathrm{VC}$-very common,

C-common, UC-uncommon,

R-rare 